\title{
Finite element simulation of railway through concrete-filled steel tube tied arch bridge based on static analysis
}

\author{
Xiaoyan Jin \\ Department of railway engineering and civil engineering, Shandong Polytechnic, Ji'nan, Shandong 250104, \\ China \\ jinxyan006@126.com
}

Keywords: Through tied arch bridge, main combination, main combination + additional force combination

\begin{abstract}
Jane has a branch structure arch bridge high complexity characteristics of large-scale. This paper uses the ANSYS software on a supporting railway simply supported tied arch bridge model, system analysis in the main combination, combination of main + additional force combination, simply supported bridge stiffness and strength of concrete, prestressed steel beam, suspender, arch rib, provide technical support for the optimization design of Jane branch bridge.
\end{abstract}

\section{Analysis model and calculation parameters}

\section{Finite element models}

The upper structure of a railway bridge is $1-48 \mathrm{~m}$ through concrete-filled steel tube simply supported arch, which falls within the beam arch composite structure. The length of the main girder of the bridge is $48 \mathrm{~m}$, and the span is $46.5 \mathrm{~m}$. The bridge consists of three parts, namely the beam part, 2 arch ribs and the 9 pairs of suspenders. Among them: the beam section is prestressed concrete structure, adopts the longitudinal beam system with two main beams, the main longitudinal beam is on both sides, the beam height is $1.6 \mathrm{~m}$, the span span ratio is $1 / 29.06$, and the Liang Kuan changes from midspan $1.4 \mathrm{~m}$ to end $2.2 \mathrm{~m}$. The thickness of the bridge deck is $0.3 \mathrm{~m}$, the end beam height is $1.6 \mathrm{~m}$, the width is $2.0 \mathrm{~m}$, the middle beam height is $1.6 \mathrm{~m}$, and the width is $0.3 \mathrm{~m}$. 1 small stringers are arranged in the center, and the slight longitudinal beam is $1.6 \mathrm{~m}$ high and $0.3 \mathrm{~m}$ wide. Beam concrete adopts C50. The suspender is composed of steel wire and is arranged in parallel. The longitudinal arrangement of the hangers is $4 \mathrm{~m}$, and the whole bridge is fitted with 9 pairs of PES (FD) 7-55 suspenders. The tensile strength standard value of the suspended cable is $1670 \mathrm{Mpa}$, the fatigue stress amplitude is $200 \mathrm{Mpa}$, and the breaking cable force is $3535 \mathrm{KN}$. The sling steel wire is executed according to GB5223 standard, with double HDPE jacket and stainless steel sheath. The anchor adopts LZM7-55 belt universal joint structure, cold casting pier head anchors. The span of arch ribs is $46.5 \mathrm{~m}$, the span to span ratio is $\mathrm{f} / \mathrm{L}=1: 6$, and the arch axis adopts two times parabolas. The arch rib adopts circular end section, the middle arch rib is high $0.8 \mathrm{~m}$ and wide $1.3 \mathrm{~m}$ equal section; the section of arch rib connecting the arch foot part changes from high $0.8 \mathrm{~m}$ to high $1.3 \mathrm{~m}$, and the width gradually varies from $1.3 \mathrm{~m}$ to $1.8 \mathrm{~m}$. Made of $16 \mathrm{~mm}$ steel plate, C50 concrete is a lot of concrete in arch tube. According to the design information, a geometric and a finite element model is established in the ANSYS software environment, as showed in figure 1. 


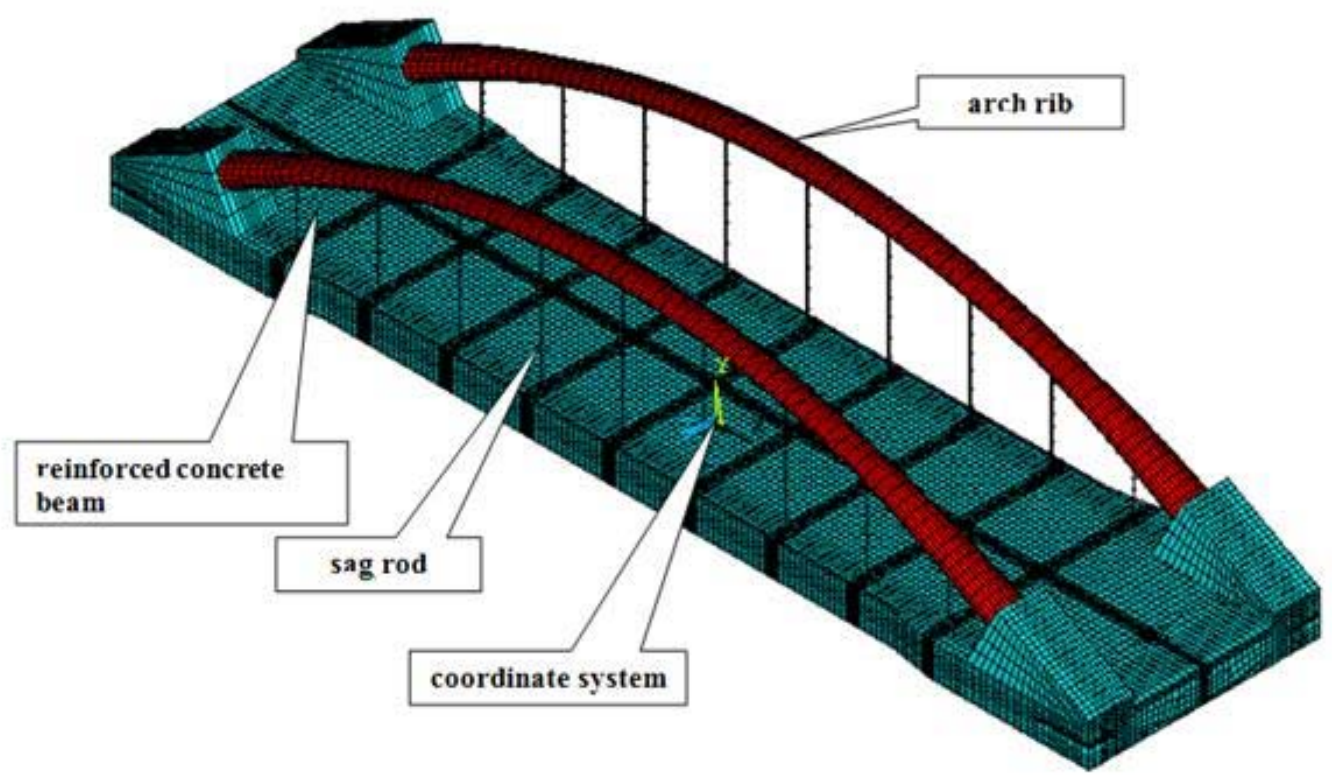

Fig 1 Calculation model of Concrete filled steel tube tied arch bridge

\section{Model unit system}

The unit adopts the system model: length - meter (m), quality (kg), time - kg seconds (s), - Newton $(\mathrm{N})$, density of $3 \mathrm{~kg} / \mathrm{M}(\mathrm{kg} / \mathrm{m} 3)$, speed - radians / sec $(\mathrm{rad} / \mathrm{s})$ and stress $(\mathrm{Pa})$, frequency - PA Hertz $(\mathrm{Hz})$.

\section{Model element type}

Unit type: concrete area using SOLID185 element to simulate the beam; using LINK180 simulation unit, beam longitudinal prestressed steel beam, end beam of prestressed steel beam, a small beam of prestressed steel beam; using BEAM189 simulation unit, suspender, arch rib; using MASS21 unit simulation bridge two dead load distribution along the bridge.

\section{Material parameters and specifications}

Establish the finite element model, use the material parameters, specifications, as shown in table 1.

Table 1 material parameters and specifications of finite element model

\begin{tabular}{|c|c|c|c|c|c|c|}
\hline Name & $\begin{array}{c}\text { Sectional } \\
\text { specifica } \\
\text { tion }\end{array}$ & $\begin{array}{c}\text { Nominal } \\
\text { diameter } \\
(\mathrm{m})\end{array}$ & $\begin{array}{c}\text { Modulus } \\
\text { of } \\
\text { elasticity } \\
(\mathrm{Pa})\end{array}$ & $\begin{array}{c}\text { Poiss } \\
\text { on } \\
\text { ratio }\end{array}$ & $\begin{array}{c}\text { Thermal } \\
\text { expansi } \\
\text { on } \\
\text { coeffici } \\
\text { ent }\end{array}$ & $\begin{array}{c}\text { Density } \\
(\mathrm{kg} / \mathrm{m} \\
3\end{array}$ \\
\hline Derrick & $\begin{array}{c}\mathrm{PES}(\mathrm{FD}) \\
7-55\end{array}$ & 0.05192 & $\begin{array}{c}2.0 \times 101 \\
1\end{array}$ & 0.28 & $\begin{array}{c}1.2 \times 10- \\
5\end{array}$ & 7850 \\
\hline Beam concrete & $\mathrm{C} 50$ & $/$ & $\begin{array}{c}3.45 \times 10 \\
10\end{array}$ & 0.2 & $\begin{array}{c}1.0 \times 10- \\
5\end{array}$ & 2400 \\
\hline $\begin{array}{c}\text { Longitudinal } \\
\text { tendon }\end{array}$ & $12-7 \varphi 5$ & $/$ & $\begin{array}{c}2.0 \times 101 \\
1\end{array}$ & 0.28 & $\begin{array}{c}1.2 \times 10- \\
5\end{array}$ & 7850 \\
\hline $\begin{array}{c}\text { End beam } \\
\text { transverse } \\
\text { reinforcement }\end{array}$ & $5-7 \varphi 5$ & $/$ & $\begin{array}{c}2.0 \times 101 \\
1\end{array}$ & 0.28 & $\begin{array}{c}1.2 \times 10- \\
5\end{array}$ & 7850 \\
\hline $\begin{array}{c}\text { Transverse } \\
\text { reinforcement of } \\
\text { center beam }\end{array}$ & $5-7 \varphi 5$ & $/$ & $\begin{array}{c}2.0 \times 101 \\
1\end{array}$ & 0.28 & $\begin{array}{c}1.2 \times 10- \\
5\end{array}$ & 7850 \\
\hline $\begin{array}{c}\text { Steel tube arch } \\
\text { Q Q } 345\end{array}$ & $/$ & $\begin{array}{c}2.0 \times 101 \\
1\end{array}$ & 0.28 & $\begin{array}{c}1.2 \times 10- \\
5\end{array}$ & 7850 \\
\hline
\end{tabular}




\section{Constraints}

For Jane Branch bridge, imposing the simple constraints, constraints for both ends of the bearing center position. According to the coordinate system shown in Figure 1, is on the side of restrictions imposed by the center of the support X, Y, zero displacement direction; on the other side of the support center, zero displacement under Y direction; both ends of the support center to coordinate in $\mathrm{Z}$ is zero, the point zero applied displacement along the $\mathrm{Z}$ direction. Fig. 2 is a schematic diagram of an applied displacement constraint[1].

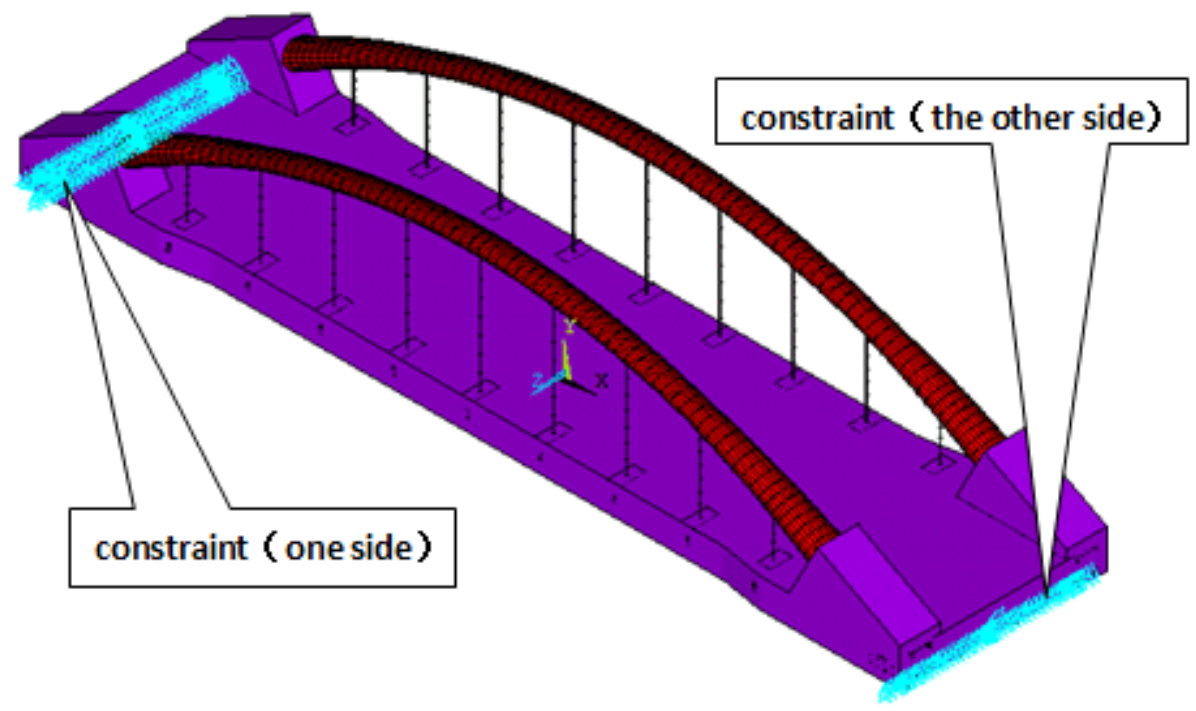

Fig 2 imposed constraints of calculation model

\section{Load handling}

According to the basic code for design of railway bridges and culverts (TB10002.1-2005), the load combinations of the bridge are associated with the main force, the main force and the additional force, and the most unfavorable combination is calculated.

\section{Main combinations}

The loads are as follows: dead load (dead weight, two stage dead load, concrete shrinkage, creep and prestress) + live load on the train (considering the vertical live load impact coefficient + lateral sways force) on the train. The processing mode is:

\section{Structure self weight}

Is Jane branch of an arch bridge with its own weight, determined by concrete and steel, the density of arch rib? In the computational model, the forward gravity acceleration along the coordinate axis y is applied.

\section{Two phase dead load}

The weight of auxiliary facilities, including: fastener, rail board, ballast, ballast wall, grade of waterproof layer, cable trough, sidewalk railings, sidewalks and other ancillary facilities in rail weight: $96 \mathrm{KN} / \mathrm{m}$; weight: $60 \mathrm{~kg} / \mathrm{m}(0.6 \mathrm{KN} / \mathrm{m})$; pavement load: $\mathrm{N}=5 \mathrm{KN} / \mathrm{m}$. These loads total: $96+0.6+5=101.6 \mathrm{KN} / \mathrm{m}$, along the entire bridge length distribution. A mass point is set at the top of the beam to simulate the mass corresponding to these weights[2].

\section{Concrete shrinkage}

The influence of arch rib concrete shrinkage is based on the basic specifications of the railway bridge and culvert (TB10002.1-2005), considering the concrete temperature dropping by 10 degrees.

In the calculation model, setting the coefficient of thermal expansion, the concrete arch rib, set the zero strain reference temperature of $30 \mathrm{DEG} \mathrm{C}$, for all other materials (concrete, reinforced beam beam, suspender, arch rib steel tube), are set to zero strain reference temperature of $20 \mathrm{DEG}$ C. In the 
calculation model, the ambient temperature is 20 degrees, and the temperature of concrete inside the arch ribs is reduced by 10 degrees.

Steel beam is prestressing force

The longitudinal, transverse and other reinforcing bars of the beam, the precipitating force $1302 \mathrm{MPa}$. In the computational model, pure stress is applied[3].

\section{Lateral rocking force}

Take $100 \mathrm{kN}$ as the center load, take the most unfavorable position, and take the horizontal perpendicular line central line acting on the rail top surface. Take the actual loading point, the bridge from a height of $0.826 \mathrm{~m}$ (including ballast height $0.65 \mathrm{M}$; rail height $0.176 \mathrm{~m}$ ), and is situated in the center of the bridge length.

\section{Live load}

The live load is medium live load, and the distribution is given in figure 3.

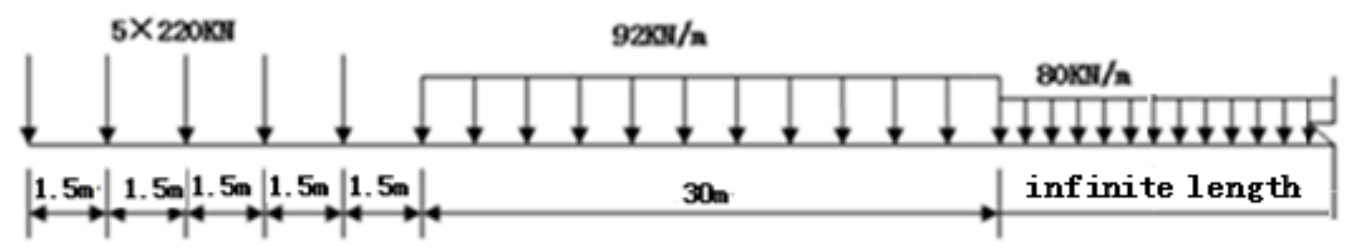

\section{Fig 3 Sketch Map of Standard live load of People's Republic of China Railway}

When calculating, the dynamic coefficients of the bridge span considered are:

$$
1+\mathrm{u}=1+a \times\left(\frac{6}{30+L}\right)=1.11
$$

Type: $\mathrm{a}=4 \times(1-\mathrm{h})=1.4 \leqslant 2 ; \mathrm{h}=0.65 \mathrm{~m}$, as the bridge filling thickness; $\mathrm{L}=46.5 \mathrm{~m}$, simple branch span arch bridge.

After the test and calculation results, in the live load in the computation model is applied to the root weight of $220 \mathrm{KN}$ : the first train load, and in the left bar in the first arch root left at $3 \mathrm{M}$, the rest of concentrated load, line set of load, orderly arrangement; line set of load, pressure to force put on the deck.

\section{Main combination}

For the above load (structural weight, two stage dead load, arch rib concrete contraction, steel beam pretension, lateral swing force, live load, etc.) in combination. The highest combined load is shown in figure 4. 


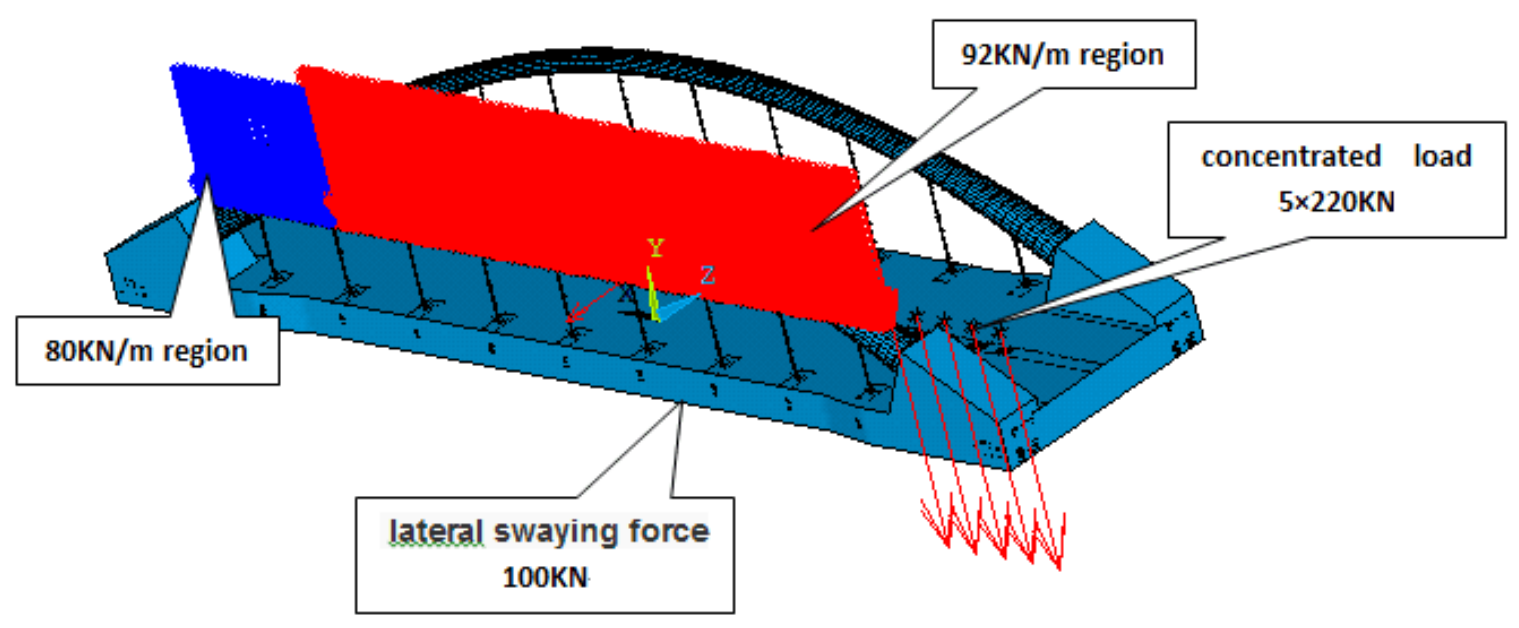

Fig 4 The main load combination diagram

\section{Main force + additional force combination}

The loading form includes the combined effects of any combination + braking force + wind force + temperature and force. Among them, the highest combination is the same as before, and the additional force is applied as follows[4].

\section{Brake force}

Depending on the $10 \%$ calculation of the live load, the vertical horizontal force acts at the top of the track at $2 \mathrm{~m}$. Take the actual loading point, the bridge from a height of $2.826 \mathrm{~m}$ (including ballast $0.65 \mathrm{~m}$ height and height of rail top rail $0.176 \mathrm{~m}$, height $2.0 \mathrm{~m}$ above). FIG. 16 illustrates the braking force

\section{Temperature force}

Overall rise and fall shall be discussed at 25 . When temperature is thought, the temperature of steel is 15 degrees higher than that of concrete. When considering cooling, the temperature of steel is 10 degrees lower than that of concrete. The temperature force is taken into account on the basis of concrete shrinkage of the arch rib (the concrete temperature is reduced by $10 \mathrm{DEG} \mathrm{C}$ ).

\section{Wind power}

The effect of transverse wind force (780MPa) on the bridge, arch rib and car body is thought.

The wind acting on the bridge is applied directly to the pressure.

The wind pressure acting on the arch ribs is applied with a concentrated transverse load (approximately, the center length of the arch rib is $39.352 \mathrm{~m}$, and the height of the arch rib cross section is $130 \mathrm{~mm}$, so that it is conservative).

The wind area of the train is estimated according to the rectangular belt of $3 \mathrm{M}$ height. The length of the train at the top of the track is $2 \mathrm{~m}$, and the length is computed according to the length of the bridge (48m). Fig. 5 shows the wind force of the bridge. 


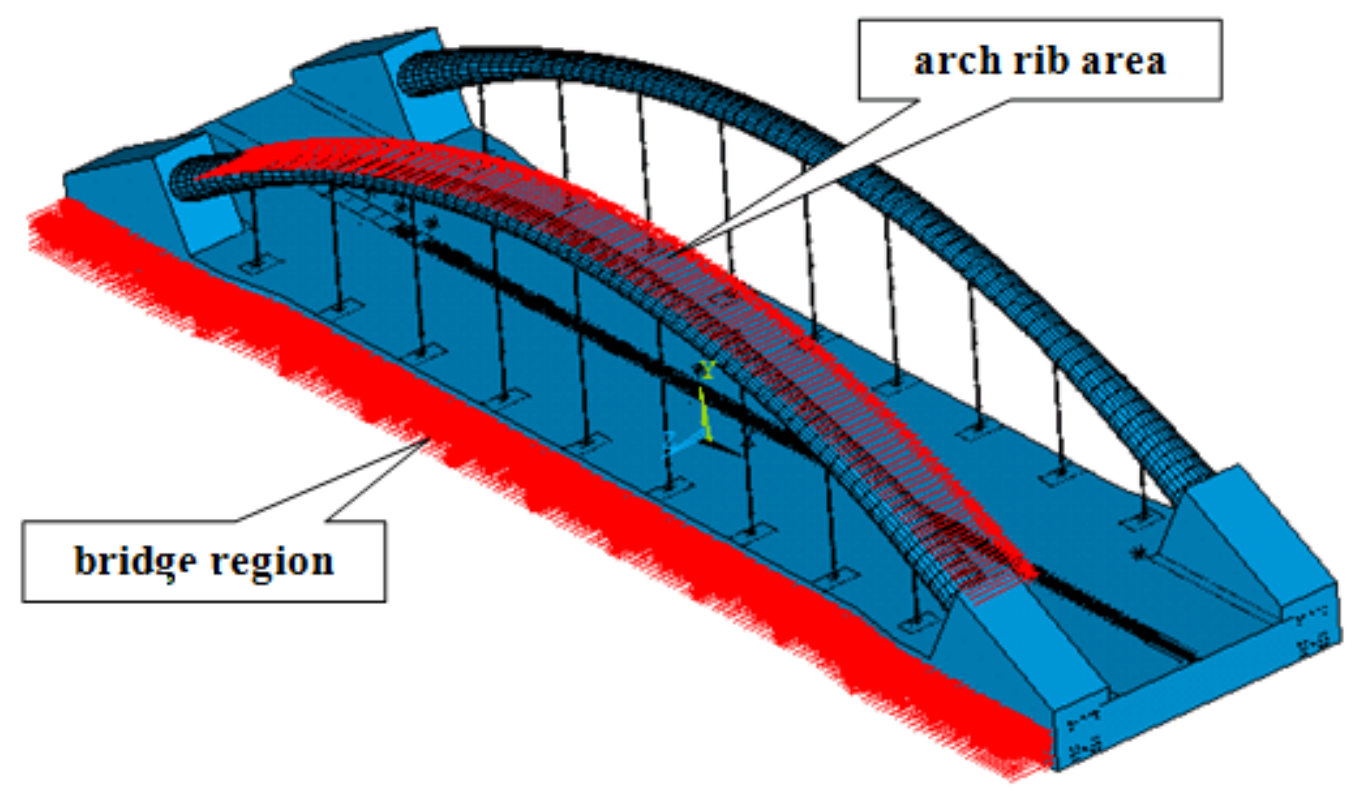

Fig 5 Schematic diagram of wind-force

\section{Strength calculation summary}

Under typical working conditions, the strength calculation result is expressed as 2 .

Table 2 strength calculation results under typical working conditions

\begin{tabular}{|c|c|c|c|c|c|c|}
\hline $\begin{array}{l}\text { Working } \\
\text { condition }\end{array}$ & $\begin{array}{l}\text { Vertical } \\
\text { deformat } \\
\text { ion of } \\
\text { bridge } \\
(\mathrm{mm})\end{array}$ & $\begin{array}{l}\text { Transver } \\
\text { se } \\
\text { deformat } \\
\text { ion of } \\
\text { bridge } \\
\text { body(m } \\
\text { m) }\end{array}$ & $\begin{array}{l}\text { Stress of } \\
\text { bridge } \\
\text { body } \\
(\mathrm{MPa})\end{array}$ & $\begin{array}{l}\text { Reinforc } \\
\text { ing bar } \\
\text { stress(M } \\
\mathrm{Pa})\end{array}$ & $\begin{array}{l}\text { Suspend } \\
\text { er } \\
\text { stress(M } \\
\mathrm{Pa})\end{array}$ & $\begin{array}{l}\text { Arch rib } \\
\text { stress } \\
(\mathrm{MPa})\end{array}$ \\
\hline Main combination & -30.0 & \pm 0.8 & +10.6 & +1160 & +408 & 88.7 \\
\hline $\begin{array}{l}\text { Combination of } \\
\text { main force }+ \\
\text { additional force } \\
\text { (overall } \\
\text { temperature rise) }\end{array}$ & -29.1 & \pm 1.0 & +11.3 & +1130 & +416 & 128 \\
\hline $\begin{array}{l}\text { Main combination } \\
+ \text { additional } \\
\text { combination } \\
\quad \text { (overall } \\
\text { cooling) }\end{array}$ & -29.5 & \pm 3.0 & +10.4 & +1170 & +413 & 88.5 \\
\hline $\begin{array}{l}\text { Design } \\
\text { requirement }\end{array}$ & $\leq 58$ & $\leq 58$ & $\leq 50)$ & $\leq 1860$ & $\leq 1670$ & $\leq 345$ \\
\hline
\end{tabular}

\section{Conclusion}

In the main, the main arch combination + additional force combination (overall heating), the main + additional force combination (overall cooling), allowed values are less than the specification of vertical deformation of beam $(\mathrm{L} / 800)$, the allowable value of transverse beams degeneration is far 
less than the standard (L/800). The vertical rigidity and lateral rigidity of tied arch bridge comply with the requirements, and the design is conservative.

Concrete bridge in the main, the main + additional force combination (overall heating), the main + additional force combination (overall cooling) compressive strength design of three kinds of load combinations under stress are far less than the C50 value of concrete. The design dimension of the longitudinal beam is conservative.

The maximum stress of the prestressed beam in the beam body is under the three combinations of the main combination, the main force + the additional force combination (the overall warming), the main force and the additional force (cooling), and the stress varies little. In addition, the overall temperature rise of the bridge is less than that of the overall cooling, and the stress of the reinforcing beam is reduced by $3 \%$.

The stress (compressive stress) of the arch rib under three kinds of load combinations is less than its compressive strength design value $(345 \mathrm{Mpa})$, and the maximum stress appears at the foot of the arch. Under the combination of main force plus additional force, the overall temperature of bridge increases by $25 \mathrm{C} 0$, and the maximum compressive stress of arch rib increases from $88.5 \mathrm{Mpa}$ to $128 \mathrm{Mpa}$, with an increase of $45 \%$.

\section{References}

[1]Morcous G, Hanna K, Deng Y, et al. Concrete-Filled Steel Tubular Tied Arch Bridge System: Application to Columbus Viaduct[J]. Journal of Bridge Engineering, 2015, 17(1):107-116.

[2]Geng Y, Wang Y, Ranzi G, et al. Time-Dependent Analysis of Long-Span, Concrete-Filled Steel Tubular Arch Bridges[J]. Journal of Bridge Engineering, 2014, 19(4):04013019.

[3]Wei J G, Chen B C, Wang J H. Analysis of construction error of pier for concrete filled steel tubular arch bridge[J]. Cancer, 2010, 118(18):4495-501.

[3]Li Y, Cai C S, Liu Y, et al. Dynamic analysis of a large span specially shaped hybrid girder bridge with concrete-filled steel tube arches[J]. Engineering Structures, 2016, 106:243-260. 